\title{
PENGARUH LAYANAN ORIENTASI TERHADAP PENGEMBANGAN DIRI SISWA KELAS VIII SMP NEGERI 1 SALAPIAN TANJUNG LANGKAT TAHUN PELAJARAN 2016/2017
}

\section{Dian Wahyudi}

\begin{abstract}
Abstrak
Tujuan penelitian ini adalah untuk mengetahui pengaruh pelaksanaan layanan orientasi sangat berpengaruh terhadap perkembangan diri siswa kelas VIII SMP Negeri 1 Salapian Tanjung Langkat Tahun Pelajaran 2016/2017. Populasi penelitian ini adalah seluruh siswa kelas VIII SMP Negeri 1 Salapian Tanjung Langkat dengan jumlah sampel sebanyak 48 orang. Hasil penelitian diperoleh kesimpulan bahwa pelaksanaan layanan orientasi terhadap pengembangan diri siswa kelas VIII SMP Negeri 1 Salapian Tanjung Langkat adalah dengan melakukan kegiatan layanan orientasi terhadap pengembangan diri siswa adalah berkaitan dengan pendidikan, kegiatan belajar dan ekstrakulikuler. Pentingnya berbagai dukungan sebagai faktor bagi berkembngnya kreativitas agar potensi kreatif individu dapat diwujudkan, diperlukan kekuatan-kekuatan pendorong dari luar yang didasari oleh potensi dari dalam individu itu sendiri. Kreativitas itu bukan semata-mata merupakan hasil dari hubungan interaktif dan dialektis antara kreatif individu dengan proses belajar dan pengalaman dari lingkungannya. Terdapat hubungan layanan orientasi terhadap pengembangan diri siswa SMP Negeri 1 Salapian Tanjung Langkat yang memiliki kaitan yang signifikan karena $F_{\text {hitung }}>F_{\text {tabel }}(5,556>1,680)$. Dari kategori pelaksanaan layanan orientasi terhadap pengembangan diri dapat diketahui bahwa skor jawaban siswa adalah 71, skor terendah 38 , nilai rata-rata skor adalah 54,84, varians adalah 50,23 dan standar deviasi adalah 7,09. Berdasarkan perolehan perhitungan di atas selanjutnya dapat diketahui bahwa nilai rata-rata diketahui bahwa 17 orang atau 34,00\% dan sebanyak 16 orang atau $32,00 \%$ berada di bawah rata-rata.
\end{abstract}

Kata Kunci: Layanan orientasi, Pengembangan diri

\section{PENDAHULUAN}

Salah satu permasalahan yang dihadapi oleh bangsa Indonesia adalah rendahnya mutu pendidikan, khususnya pendidikan dasar dan menengah. Berbagai usaha telah dilakukan untuk meningkatkan mutu pendidikan nasional, antara lain melalui berbagai pelatihan dan peningkatan kualitas guru, penyempurnaan kurikulum, pengadaan buku dan alat pelajaran, perbaikan sarana dan prasarana pendidikan lain, dan peningkatan mutu manajemen sekolah. Namun demikian, berbagai indikator mutu pendidikan belum menunjukkan peningkatan yang memadai.

Upaya peningkatan kualitas pendidikan di Indonesia tidak pernah berhenti. Berbagai terobosan baru terus dilakukan oleh pemerintah melalui Depdiknas. Upaya itu antara lain dalam pengelolaan sekolah, peningkatan sumber daya tenaga pendidikan, pengembangan/penulisan materi ajar, serta pengembangan Paradigma baru dengan metodologi pengajaran.

Pada hakekatnya pendidikan bertujuan untuk membentuk manusia yang berkualitas yang diharapkan keberadaannya kelak menjadi tenaga pembangunan yang profesional. Tujuan pendidikan tersebut dirumuskan karena menyadari bahwa pembangunan bangsa dan negara dalam berbagai aspek kehidupan tidak akan terwujud tanpa didukung oleh adanya Sumber Daya 
Manusia (SDM) yang berkualitas.

Selama mengikuti pelaksanaan pendidikan ini siswa mendapat pembinaan dan bimbingan dari pihak sekolah, khususnya dilakukan oleh guru dengan maksud mengarahkan dan membentuk sikap maupun prilaku yang baik pada diri siswa. Namun terkadang ada sebagian siswa yang kurang merespon terhadap kegiatan pembinaan dan bimbingan yang dilakukan oleh guru, sehingga munculnya bentuk-bentuk prilaku yang kurang baik. Padahal pembinaan dengan melalui bimbingan dan arahan yang diberikan guru dimaksudkan untuk kebaikan siswa di masa yang akan datang.

Selama pelaksanaan pembelajaran yang diikuti oleh siswa, tentu ada gangguan pada diri siswa, terutama menyangkut kemampuan siswa dalam mengikuti aktivitas belajar yang dilaksanakan di sekolah. Gangguan belajar yang terjadi atau dialami oleh siswa bisa berakibat terhadap keberhasilan siswa dalam mengikuti aktivitas belajar di sekolah. Di antara gangguan yang dialami siswa adalah ketidakmampuan siswa dalam melakukan hubungan baik di sekolah, baik hubungan sesama siswa maupun hubungan dengan guru. Gangguan juga bisa dirasakan oleh siswa berupa ketidakmampuan dalam bersolidaritas dengan sesama siswa di sekolah. Ketidakmampuan siswa melakukan solidaritas di sekolah bisa berdampak pada kurangnya dukungan sesama siswa dalam melakukan aktivitas belajar di sekolah. Menyikapi kondisi siswa seperti ini, tentu saja diperlukan bimbingan dan konseling yang dilaksanakan oleh guru pembimbing untuk membantu siswa menyelesaikan masalah yang dihadapinya. Salah satu jenis layanan yang diberikan kepada siswa, adalah Layanan Orientasi, yang memungkinan peserta didik memahami lingkungan baru, terutama lingkungan sekolah dan obyek- obyek yang dipelajari, untuk mempermudah dan memperlancar berperannya peserta didik di lingkungan yang baru itu, sekurang-kurangnya diberikan dua kali dalam satu tahun yaitu pada setiap awal semester.

Tujuan layanan orientasi adalah agar peserta didik dapat beradaptasi dan menyesuaikan diri dengan lingkungan baru secara tepat dan memadai, yang berfungsi untuk pencegahan dan pemahman. Agar pelaksanaan layanan orientasi ini dapat dihayati dan diikuti oleh siswa, maka guru pembimbing harus mampu menyelenggarakan layanan itu dengan baik. Guru pembimbing harus dapat membantu siswa mengembangkan diri secara optimal, sehingga siswa dapat tertarik dan berminat untuk mengikuti kegiatan layanan orientasi.

Dari kegiatan layanan orientasi ini maka akan terbentuk kemandirian yang lebih baik pada diri siswa di sekolah. Upaya inilah antara lain yang dilakukan dalam pelayanan bimbingan dan konseling khususnya layanan orientasi. Konselor sekolah dalam penanganan siswa yang bermasalah pngembangan pribadinya akan membentuk moral siswa sesuai dengan yang diharapkan di sekolah dalam masyarakat luas. Memberikan bimbingan dapat dilakukan dengan berbagai layanan dan bidang pengembangan. Dengan layanan orientasi dapat membantu siswa sekaligus dalam memecahkan masalah-masalah pribadi siswa. Layanan yang diberikan dimaksudkan agar siswa dapat terbimbing, agar individu dapat mengenal dan berhubungan dengan lingkungan sosial yang dilandasi dengan budi pekerti luhur dan rasa tanggung jawab.

Dalam observasi awal di SMP 1 Negeri Salapian Tanjung Langkat diketahui bahwa siswa yang ada di sekolah ini memiliki keberagaman dengan latar belakang kehidupan sosial yang berbeda-beda. Akibat keberagaman siswa yang ada di sekolah ini terjadi beberapa permasalahan yang menyangkut pengembangan diri siswa tersebut dalam belajar di lingkungan 
sekolah seperti adanya kelompok- kelompok yang terdiri atas siswa memiliki kepribadian yang tinggi dan ada pula siswa yang memiliki kepercayaan diri yang rendah. Selama pelaksanaan pembelajaran di sekolah ini ditemukan bahwa siswa mempunyai nilai belajar sangat rendah, hal ini terlihat ketika di dalam kelas, siswa malas, banyak bermain dalam belajarnya, tidak merespon setiap pertanyaan dari guru ketika dalam proses pembelajaran, tidak mengikuti kegiatan kelompok belajar, jarang membaca buku yang berkaitan dengan mata pelajaran dan tidak mengerjakan tugas-tugas yang diberikan guru di sekolah. Siswa terkesan tidak aktif dalam belajar sehingga suasana belajar tidak kondusif dan menyebabkan rendahnya hasil belajar siswa.

Penyebab dari munculnya masalah ini adalah karena kurangnya perhatian dari guru sendiri dalam menumbuhkan rasa percaya diri kepada siswa, dan kurangnya kerjasama antara konselor sekolah dan guru mata pelajaran dalam memberikan motivasi kepada siswa agar jangan minder dengan teman-temannya. Sehingga jika siswa memiliki kepribadian yang kuat dan baik maka dalam belajarpun ia akan lebih giat dalam mengikuti pelajaran di sekolah sehingga hasil belajarnya juga akan baik. Konselor sekolah kurang memberikan layanan bimbingan dan konseling agar siswa-siswa memiliki kepribadian dan rasa percaya diri yang baik, dimana akan dapat menimbulkan motivasi belajarnya.

\section{KAJIAN TEORI}

\section{Pengertian Bimbingan dan Konseling}

Secara harfiah bimbingan dapat diartikan sebagai suatu "tindakan menolong" atau "memberikan bantuan." Sedangkan konseling dilaksanakan kepada seseorang adalah upaya membantu individu melalui proses interaksi yang bersifat pribadi antara konselor dan konseling agar konseli mampu memahami diri dan lingkungannya, mampu membuat keputusan dan menentukan tujuan berdasarkan nilai yang diyakininya sehingga konseli merasa bahagia dan efektif prilakunya.

Menurut Nurihsan (2006:42), bimbingan adalah upaya pengembangan seluruh aspek kepribadian siswa, pencegahan terhadap timbulnya masalah yang akan menghambat perkembangannya dan menyelesaikan masalah-masalah yang dihadapinya, baik sekarang maupun pada masa yang akan datang. Sedangkan Walgito (2005:6) menyatakan bimbingan adalah proses pemberian bantuan yang dilakukan oleh orang yang ahli kepada seseorang atau beberapa orang individu, baik anak-anak, remaja maupun dewasa, agar orang yang dibimbing dapat mengembangkan kemampuan dirinya sendiri dan mandiri, dengan memanfaatkan kekuatan individu dan sarana yang ada dan dapat dikembangkan berdasarkan norma-norma yang berlaku.

Menurut pendapat Hikmawati (2011:1) konseling adalah usaha membantu konseli/ klien secara tatap muka dengan tujuan agar klien dapat mengambil tanggung jawab sendiri terhadap berbagai persoalan atau masalah khusus. Dengan kata lain teratasinya masalah yang dihadapi oleh konseli/ klien. Sedangkan menurut Prayitno dan Erman (2009:105), konseling adalah proses pemberian bantuan yang dilakukan melalui wawancara konseling oleh seorang ahli (disebut konselor) kepada individu yang sedang mengalami sesuatu masalah (disebut klien) yang bermuara pada teratasinya masalah yang dihadapi oleh klien. Dari penjelasan di atas dapat dipahami bahwa konseling adalah bantuan yang diberikan kepada klien oleh seorang konselor yang memiliki kemampuan profesional untuk lebih mampu menyesuaikan diri secara efektif terhadap dirinya sendiri dan lingkungannya. Konseling merupakan suatu cara yang efektif digunakan dalam penyesuaian diri untuk menyelesaikan masalah yang sedang dihadapi. Seorang yang sedang menghadapi masalah dibimbing dan diarahkan dalam penyelesaian 
masalah itu.

\section{Bimbingan dan Konseling di Sekolah}

Berbagai jenis bimbingan dan konseling perlu dilakukan sebagai wujud penyelenggaraan pelayanan bimbingan dan konseling terhadap sasaran layanan, yaitu peserta didik di sekolah. Nurihsan (2006:42) menyatakan bimbingan dan konseling adalah upaya pengembangan seluruh aspek kepribadian siswa, pencegahan terhadap timbulnya masalah yang akan menghambat perkembangannya, dan menyelesaikan masalah-masalah yang dihadapinya, baik sekarang maupun pada masa yang akan datang. Salah satu bentuk kegiatan bimbingan konseling di sekolah adalah melalui layanan orientasi. Layanan orientasi yaitu layanan bimbingan dan konseling yang memungkinkan peserta didik atau klien memahami lingkungan seperti lingkungan sekolah yang baru dimasukinya (Nurihsan, 2006:45). Dengan adanya layanan orientasi ini maka siswa akan mudah untuk berprestasi dengan lingkungan yang baru.

\section{Pengertian Layanan Orientasi}

Menurut Prayitno dan Erman (2010:259), layanan yang memungkinan peserta didik memahami lingkungan baru, terutama lingkungan sekolah dan obyek-obyek yang dipelajari, untuk mempermudah dan memperlancar berperannya peserta didik di lingkungan yang baru itu, sekurang-kurangnya diberikan dua kali dalam satu tahun yaitu pada setiap awal semester. Sedangkan Winkel dan Sri (2006:21) menyatakan layanan orientasi adalah usaha untuk membekali para siswa dengan pengetahuan tentang data dan fakta yang ada di lingkungan sekolah, pekerjaan dan bidang perkembangan pribadi-sosial, supaya mereka dengan belajar tentang lingkungan hidupnya lebih mampu mengatur dan merencanakan kehidupannya sendiri. Dengan demikian disimpulkan layanan informasi adalah suatu kegiatan atau usaha untuk membekali para siswa tentang berbagai macam pengetahuan supaya mereka mampu mengambil keputusan secara tepat dalam kehidupanya.

Setiap layanan dalam bimbingan dan konseling mempunyai tujuan yang ingin dicapai. Demikian juga layanan orientasi mempunyai tujuan sebagaimana pendapat Purwoko (2010:281) yaitu: (1) para siswa dapat mengorientasikan dirinya kepada informasi yang diperolehnya terutama untuk kehidupannya, baik semasa masih di sekolah maupun setelah menamatkan sekolah; (2) para siswa mengetahui sumber-sumber informasi yang diperlakukan; (3) para siswa dapat menggunakan kegiatan kelompok sebagai sarana memperoleh informasi; dan (4) para siswa dapat memilih dengan tepat kesempatan-kesempatan yang ada dalam lingkungannya sesuai dengan minat dan kemampuannya.

Sementara itu menurut Lahmudin (2006:18), layanan orientasi adalah untuk membekali siswa atau individu dengan berbagai pengetahuan dan pengalaman tentang berbagai pengetahuan dan pengalaman tentang berbagai hal yang berguna untuk mengenal diri, merencanakan dan mengembangkan pola kehidupan mereka sebagai siswa, anggota keluarga dan masyarakat.

\section{Pengertian Pengembangan Diri}

Pengembangan diri merupakan kegiatan pendidikan di luar mata pelajaran sebagai bagian integrasi dari kurikulum sekolah/ madrasah. Kegiatan pengembangan diri merupakan upaya pembentukan watak dan kepribadian peserta didik yang dilakukan melalui kegiatan pelayanan konseling berkenaan dengan masalah pribadi dan kehidupan sosial, kegiatan belajar, dan pengembangan karir, serta kegiatan ekstrakurikuler. Menurut Yusuf (2007:1), pengembangan diri bukan merupakan mata pelajaran yang harus diasuh oleh guru. Kegiatan pengembangan diri difasilitasi dan atau dibimbing oleh konselor, guru, atau tenaga kependidikan 
yang dapat dilakukan dalam bentuk kegiatan ekstrakurikuler. Kegiatan pengembangan diri dilakukan melalui kegiatan pelayanan konseling yang berkenaan dengan masalah diri pribadi dan kehidupan sosial, belajar, dan pengembangan karir konseling.

Pengembangan diri adalah kegiatan sekolah yang bertujuan memberikan kesempatan kepada peserta didik utuk mengembangkan dan mengekspresikan diri sesuai dengan kebutuhan, bakat, minat setiap peserta didik yang disesuaikan dengan kondisi sekolah. Kegiatan pengembangan diri di sekolah memberi peluang kepada peserta didik untuk dapat mengembangkan kemampuan- kemampuan yang ada dalam diri setiap individu. Kegiatankegiatan di sekolah yang mengembangkan kreativitas siswa dapat dilaksanakan dengan dukungan dari guru bidang studi, konselor. Salah satunya dapat disalurkan melalui berbagai kegiatan ekstra kurikuler yang disediakan sekolah, di bawah bimbingan pembina ekstra kurikuler terkait, baik pembina dari unsur sekolah maupun luar sekolah. Kegiatan ekstrakurikuler yang lazim diselenggarakan di sekolah, seperti: pramuka, olahraga, kesenian, PMR, kerohanian atau jenis-jenis ekstra kurikuler lainnya yang sudah terorganisir dan melembaga bukanlah satusatunya kegiatan untuk pengembangan diri.

\section{METODE PENELITIAN}

\section{Lokasi dan Waktu Penelitian}

Penelitian dilakukan di SMP Negeri Salapian Tanjung Langkat Tahun Pelajaran 2016/2017. Waktu penelitian dilaksanakan pada semester ganjil terhadap siswa kelas VIII SMP Negeri 1 Salapian Tanjung Langkat Tahun Pelajaran 2016/2017.

\section{Populasi dan Sampel}

Populasi adalah wilayah generalisasi yang terdiri atas objek/subjek yang mempunyai kualitas dan karakteristik tertentu yang diterapkan oleh peneliti untuk dipelajari dan kemudian ditarik kesimpulannya (Sugiyono, 2010:117). Adapun yang menjadi populasi dalam penelitian ini adalah seluruh siswa kelas VIII SMP Negeri 1 Salapian Tanjung Langkat Tahun Pelajaran 2016/2017 yang terdiri dari 4 kelas dengan jumlah keseluruhan 160 orang. Sampel adalah bagian dari populasi yang diambil untuk dijadikan penelitian. Sampel penelitian ditentukan sebanyak $30 \%$ dari populasi, yaitu $30 \% \times 160$ siswa $=48$ siswa. Teknik pengambilan sampel ini adalah teknik random sampling (secara acak).

\section{Definisi Operasional Variabel}

\section{Layanan Orientasi}

Layanan yang memungkinan peserta didik memahami lingkungan baru, terutama lingkungan sekolah dan obyek-obyek yang dipelajari, untuk mempermudah dan memperlancar berperannya peserta didik di lingkungan yang baru itu.

2. Pengembangan diri

Pengembangan diri merupakan kegiatan pendidikan di luar mata pelajaran yang penilaiannya dilakukan secara kualitatif. Dalam pengembangan diri termasuk kegiatan ekstra kurikuler membantu pengembangan peserta didik sesuai kebutuhan, potensi, bakat, minat, krativitas serta kondisi diri mereka.

\section{Teknik Analisis Data}

\section{Uji Aosiatif (Pengaruh)}

Untuk menghadap seberapa besar pengaruh layanan orientasi terhadap pengembangan diri siswa kelas VIII SMP Negeri 1 Salapian Tanjung Langkat Tahun Pelajaran 2016/2017 dengan menggunakan analisis korelasi sebagaimana dinyatakan Arikunto (2010:213): 


\section{Uji Hipotesis}

Untuk menguji hipotesis digunakan uji t-tabel, dengan rumus sebagai dinyatakan Sugiyono (2010:257) berikut:

$$
t=\frac{r \sqrt{N-2}}{\sqrt{1-r^{2}}}
$$

\section{HASIL DAN PEMBAHASAN \\ Deskripsi Hasil Penelitian \\ Pelaksanaan Layanan orientasi}

Berdasarkan hasil penelitian terhadap pelaksanaan layanan orientasi terhadap pengembangan diri siswa kelas VIII SMP Negeri 1 Salapian Tanjung Langkat. Adapun pengaruh layanan orientasi layanan terhadap pengembangan diri berkaitan dengan: (a) memahami apa itu layanan orientasi, (b) memahami jenis-jenis layanan orientasi, (c) layanan orientasi memberi pengetahuan dan pemahaman, dan (d) orientasi kegiatan ekstra kurikuler. Untuk memperoleh data tentang pelaksanaan layanan orientasi terhadap pengembangan diri dengan indikator memahami layanan orientasi, memahami jenis-jenis layanan orientasi. Layanan orientasi memberi pengetahuan dan pemahaman, orientasi kegiatan ekstra kurikuler selanjutnya peneliti mengajukan instrumen kepada siswa sebagai responden penelitian. Setelah diajukan angket atau instrumen penelitian selanjutnya peneliti melakukan penskoran terhadap frekuensi perolehan jumlah atau skor angket berdasarkan indikator penelitian yang diajukan kepada responden penelitian.

Berdasarkan hasil penelitian diketahui bahwa skor jawaban siswa terhadap Memahami apa itu layanan orientasi skor tertinggi adalah 71 , skor terendah 38 , nilai rata-rata skor adalah 54,84 , varians adalah 50,23 dan standar deviasi adalah 7,09. Berdasarkan perolehan perhitungan di atas selanjutnya dapat diketahui bahwa nilai rata-rata diketahui bahwa 17 orang atau 34,00\% berada pada skor rata-rata, sebanyak 17 orang atau $34 \%$ berada di atas skor rata-rata dan sebanyak 16 orang atau $32,00 \%$ berada di bawahrata-rata.

Selanjutnya kategori pengaruh layanan orientasi terhadap pengembangan diri dapat dikemukakan pada tabel berikut.

Kategori Pelaksanaan Layanan Orientasi terhadap Pengembangan Diri

\begin{tabular}{|c|c|c|c|c|}
\hline No & Interval & Frekuensi & Fabsolut & \\
\hline 1 & 62,75 keatas & 7 & 14,00 & Tinggi \\
\hline 2 & 54,50 s/d 61,75 & 19 & 38,00 & Sedang \\
\hline 3 & 46,25 s/d 54,50 & 18 & 36,00 & Kurang \\
\hline 4 & 45,25 kebawah & 6 & 12,00 & Rendah \\
\hline Jumlah & & 50 & 100,00 & \\
\hline
\end{tabular}

\section{Pengembangan Diri Siswa}

Pengembangan diri adalah suatu kegiatan yang bertujuan memberikan kesempatan kepada peserta didik untuk mengembangkan dan mengekspresikan diri sesuai dengan kebutuhan, bakat dan minat setiap peserta didik sesuai dengan kondisi sekolah kegiatan pengembangan diri difasilitasi atau dibimbing oleh konselor, guru atau tenaga kependidikan yang dapat dilakukan 
dalam bentuk kegiatan ekstrakurikuler. Kegiatan pengembangan diri dilakukan melalui pelayanan konseling yang berkenaan dengan masalah diri pribadi dan kehidupan sosial, belajar dan pengembangan karir peserta didik. Karena bukan sebuah mata pelajaran, penilaian kegiatan pengembangan diri dilakukan secara kualitatif bukan kuantitatif seperti pada mata pelajaran.

Pengembangan diri merupakan bagian pembelajaran yang diarahkan agar dalam kegiatankegiatan yang dapat menunjang pengembangan bakat dan minat serta pengembnagn karir, salah satu wahanauntuk mewujudkan tujuan tersebut dapat diaplikasikan dalam kegiatan pembiasaan sebagaimana yang telah diperkenalkan. Salah satu kegiatan ekstraa kulikuler merupaakan kegiatan yang dilakukan disekolah diluar jaam pelajaaraan yang daapat mengembangkan kebutuhan, bakat, serta minat siswa sesuaidengan kondisi sekolah.

Pengembangan diri siswa yang diteliti dalam pelaksanaan penelitian ini adalah terkait dengan indikator: (a) jenis-jenis kegiatan eksta kurikuler di sekolah, pemilihan pengembangan diri, dan (c) bakat, minat dan potensi yang dimiliki. Berdasarkan hasil penelitian diketahui perolehan skor terhadap pengembangan diri diketahui skor tertinggi adalah 97, skor terendah 58, nilai rata-rata adalah 76,80 , varians adalah 88,16 dan standar deviasi adalah 9,39. Rata-rata diketahui bahwa 14 orang atau $28,00 \%$ berada pada skor rata-rata, sebanyak 15 orang atau $30,00 \%$ berada di atas skor rata-rata dan sebanyak 21 orang atau $42,00 \%$ berada di bawah ratarata. Selanjutnya kategori kreativitas siswa dapat dilihat pada tabel berikut.

Kategori Pengembangan Diri Siswa

\begin{tabular}{|c|c|c|c|c|}
\hline No & Interval & F absolut & F relative & Kategori \\
\hline 1 & 87,25 keatas & 6 & 12,00 & Tinggi \\
\hline 2 & $67,75 \mathrm{~s} / \mathrm{d} 86,50$ & 21 & 42,00 & Sedang \\
\hline 3 & $67,75 \mathrm{~s} / \mathrm{d} 76,50$ & 18 & 36,00 & Kurang \\
\hline 4 & 66,75 keatas & 5 & 10,00 & Rendah \\
\hline \multicolumn{2}{r|}{} & 50 & 100,00 & \\
\hline
\end{tabular}

\section{Pembahasan}

Berdasarkan hasil penelitian di atas membuktikan bahwa adanya kaitan yang positif antara pelaksanaan layanan orientasi terhadap pengembangan diri siswa di SMP Negeri 1 Salapian Tanjung Langkat. Dari hasil uji korelasi antara pelaksanaan layanan orientasi terhadap pengembangan diri siswa dengan kenakalan remaja pada taraf signifikansi $\alpha=5 \%$ adaalah 0,625 . Nilai $r_{\text {hitung }}>r_{\text {tabel }}$ atau $0,625>0,237$ dan berdasarkan hasil $t_{\text {hitung }}$ diperoleh $t_{\text {hitung }}>t_{\text {tabel }}(5,0337>$ $1,680)$.

. Hasil pengujian di atas membuktikan bahwa antaara pelaaksanaan layanan orientasi terhadap pengembangan diri siswa SMP Negeri 1 Salapian Tanjung Langkat memiliki kaitan yang signifikan yang berarti bahwa baiknya pengembangan diri didukung oleh pelaksanaan layanan orientasi. Pelaksanaan layanan orientasi terhadap pengembangan diri merupakan suatu kelompok dimana terdapat ikatan di antara anak-anak yang bersamaan usianya. Hal-hal yang berhubungan dengan tingkah laku, minat, sikap termasuk pikiran remaja yang banyak dipengaruhi oleh teman kelompok mereka, disamping pengaruh dari orang tua, orang tua tidak akan resah bila anaknya bergaul dengan pelaksanaan yang berkembang dalam masyarakat

Siswa sudah menunjukkan penilaian, sikap dan keinginan yang positif terhadap pelaksanaan dan tugas-tugas guru pembimbing dalam melaksanaan orientasi terhadap 
pengembangan diri SMP Negeri 1 Tanjung Langkat. Hal ini dibuktikan dengan tanggapan siswa serta beberapa tindakan-tindakan yang mereka lakukan adalah upaya untuk bisa membentuk kerjasama dengan guru pembimbing dan tumbuhnya kesadaran dalam diri siswa untuk merubah tindakan yang tidak baik yang merugikan diri mereka sendiri.

Hubungan siswa dengan guru pembimbing sudah menunjukkan keharmonisan dan kejasama yang baik. Perilaku ini dapat dibuktikan oleh kemampuan siswa dalam menempatkan posisi dirinya sebagai seorang siswa yang memiliki tugas dan kewajiban yang harus dipenuhi. Sebagai seorang siswa tentunya harus selalu bersikap sopan santun kepada guru, dapat menjadikan guru sebagai tauladan yang baik. Kesadaran ini tentunya akan lebih memberikan pemahaman kepada siswa bahwa ada beberapa perilaku yang sebenarnya tidak dibenarkan yaitu siswa melawan guru, pertikaian dengan guru dan siswa tidak respon terhadap tugas-tugas yang diberikan oleh guru.

Hubungan yang harmonis, iklim edukatif yang baik tentunya menjadi modal dasar yang harus ditumbuh kembangkan dalam penyelenggaraan aktivitas belajar mengajar disekolah. Hal ini sepenuhnya sudah dilakukan terutama oleh guru bimbingan konseling sekolah SMP Negeri 1 Tanjung Langkat. Untuk membuat siswa agar lebih bersikap sopan dan santun kepada guru, menjadikan guru sebagai tauladan dalam segala tingkah laku agar terjalin hubungan yang baik.

Usaha yang dilakukan oleh guru bimbingan konseling sekolah SMP Negeri1 Salapian tanjung Langkat adalah memberikan bimbingan yang baik dalam membentuk perilaku siswa sehingga siswa memiliki penilaian yang positif terhadap kinerja bimbingan dan konseling sehingga mendukung pula terhadap keinginan siswa dalam mengikuti kegiatan bimbingan dan konseling terutama dalam pelaksanaan bimbingan belajar di SMP Negeri 1 Salapian. Konsep atau pengertian merupakan defenisi secara singkat dari sekelompok fakta atau gejala. Konsep adalah juga sebagai defenisi yang dipakai para peneliti untuk menggambarkan secara abstrak suatu fenomena. Jadi konsep adalah definisi dari apa yang perlu diamati.

Tujuan layanan orientasi adalah agar peserta didik dapat beradaptasi dan menyesuaikan diri dengan lingkungan baru secara tepat dan memadai, yang berfungsi untuk pencegahan dan pemahman.

Agar pelaksanaan layanan orientasi ini dapat dihayati dan diikuti oleh siswa, maka guru pembimbing harus mampu meyelenggarakan layanan itu dengan baik. Guru pembimbing harus dapat membantu siswa mengembangkan diri secara optimal, sehingga siswa dapat tertarik dan berminat untuk mengikuti kegiatan layanan orientasi, sehingga mampu membantu siswa mengembangkan dan menyalurkan bakat, minat dan potensi yang dimiliki secara tepat dan sesuai dan Pengembangan diri adalah kegiatan sekolah yang bertujuan memberikan kesempatan kepada peserta didik untuk mengembangkan dan mengekspresikan diri sesuai dengan kebutuhan, bakat, minat setiap peserta didik yang disesuaikan dengan kondisi sekolah.

\section{PENUTUP}

\section{Simpulan}

1. Pelaksanaan layanan informasi bidang bimbingan SMP Negeri 1 Salapian Tanjung Langkat adalah dengan melakukan kegiatan layanan informasi bidang pengembangan belajar yang diberikan kepada siswa adalah berkaitan dengan: pendidikan, kegiatan belajar, dan ekstrakulikuler.

2. Pentingnya berbagai dukungan sebagai faktor bagi perkembangannya kreativitas agar 
potensi kreatif individu dapat diwujudkan, diperlukan kekuatan-kekuatan pendorong dari luar yang didasari oleh potensi dalam diri individu itu sendiri. Kreativitas ini bukan semata-mata merupakan hasil dari hubungan interaktif dan dialektis antara potensi kreatif individu dengan proses belajar dan pengalaman dari lingkungannya.

3. Terdapat hubungan antara layanan orientasi terhadap pengembangan diri dalam bidang ilmu pengetahuan siswa dan kreativitas siswa SMP Negeri 1 Salapian Tanjung Langkat.

\section{Saran}

1. Bagi kepala sekolah SMP Negeri 1 Salapian Tanjung Langkat untuk lebih memperhatikan dan melakukan pengawasan dalam melaksanaan bimbingan daan konseling di sekolah, khususnya pelaksanaan layanan konseling individu sehingga dapat meningkatkan kualitas layanan bimbingan dan konseling disekolah dengan tepat.

2. Kepada konselor sekolah guna meningkatkan kinerja agar dapat meningkatkan kualitas layanan konseling individual sehingga dapat membantu mengatasi permasalahan belajar siswa

3. Kepada siswa yang mampu memahami materi layanan konseling individual yang diberikan guna lebih bermanfaat terhadaap kemampuan siswa mengatasi masalah yang dihadapi dalam aktivitas belajar.

\section{REFERENSI}

Arikunto, Suharsimi. 2006. Prosedur Penelitian Suatu Pendekatan Praktik. Jakarta: Rineka Cipta

Hikmawati, Fenti. 2011. Bimbingan dan Konseling. Jakarta: Grafindo Persada Lahmudin. 2006. Konsep-konsep Dasar Bimbingan Konseling. Bandung: Cita Pustaka Media Printis

Nurihsan, Juntika Achmad. 2006. Bimbingan dan Konseling dalam Berbagai Kehidupan. Bandung: Refika Aditama

Prayitno dan Erman Amti. 2010. Dasar-dasar Bimbingan Konseling. Jakarta: Rineka Cipta

Purwoko, Budi. 2008. Orgunisasi dan Managemen Bimbingan Konseling. Surabaya: Unesa University Press

Sugiyono. 2010. Metode Penelitian Pendidikan. Bandung: Alfabeta

Walgito, Bimo. 2005. Bimbingan Penyuluhan di Sekolah. Jakarta: Bina Aksara

Winkel, WS. dan Sri Hastuti. 2006. Bimbingan dan Konseling di Institusi Pendidikan, Jogjakarta: Media Abadi

Yusuf, Syamsu LN. 2007. Rambu-Rambu Penyelenggaraan Bimbingan dan Konseling Dalam Jalur Pendidikan Formal. Jakarta: Dirjen PMPTK 
